\title{
EKSISTENSI PENGADILAN HAK ASASI MANUSIA DI INDONESIA
}

\author{
Asrullah, Fadli Yasser Arafat Juanda, Ika Novitasari \\ Email: asrullah@unsulbar.ac.id \\ Univesitas Sulawesi Barat
}

\begin{abstract}
Abstrak
Untuk menjamin pengakuan dan perlindungan terhadap HAM, Indonesia telah memiliki beberapa instrumen hukum yang berkaitan dengan HAM. Terkhusus untuk mengadili pelanggaran HAM yang berat, dilahirkan Undang-Undang Nomor 26 Tahun 2000 tentang Pengadilah Hak Asasi Manusia. Pengadilan HAM adalah pengadilan yang berada dilingkungan Peradilan Umum yang hanya bertugas dan berwenang untuk memeriksa dan memutus perkara pelanggaran HAM yang berat saja. Penyelidikan perkara pelanggaran HAM yang berat merupakan kewenngan Komisi Nasional Hak Asasi Manusia. Penyidikan dan penuntutan perkara Pelanggaran HAM yang berat merupakan kewenangan Jaksa Agung.
\end{abstract}

Kata kunci: Eksistensi, Pengadilan, Hak Asasi Manusia, Indonesia

\section{Pendahuluan}

Sejarah tentang HAM sesungguhnya dapat dikatakan hampir sama tuanya dengan keberdaan umat manusia di muka bumi. Mengapa dikatakan demikian, karena HAM memiliki sifat yang selalu melekat (inherent) pada diri setiap manusia, sehingga eksistensinya tidak dapat dipisahkan dari kehidupan umat manusia.Berbagai upaya untuk mewujudkan HAM dalam kehidupan nyata sejak dahulu hingga sekarang ini, tercermin dari perjuangan manusia dalam mempertahankan harkat dan martabatnya dari tindakan sewenang-wenang dan tiran. Timbulnya kesadaran manusia akan hakhaknya sebagai manusia merupakan salah satu faktor penting yang melatar belakangi dan melahirkan gagasan yang kemudian dikenal sebagai HAM.

Babak baru perkebangan HAM secara internasional terjadi stelah dunia mengalami kehancuran luar baiasa akibat Peran Dunia ke II. Terbentuknya Perserikatan 
Bangsa-Bangsa (PBB) sebagai organisasi internasional pada tahun 1945 tidak dipungkiri memiliki pengaruh yang sangat besar bagi perkembangan HAM dikemudian hari. Hal itu antara lain, ditandai dengan adanya pengakuan didalam Piagam PBB sendiri (United Nations Charter) akan eksistensi HAM dan tujuan didirikannya PBB sendiri yaitu dalam rangka mendorong penghormatan terhadap HAM secara internasional. Walaupun didalam piagam belum dirumuskan secara jelas apa yang dimaksud dengan HAM. Tonggak sejarah pengaturan HAM yang bersifat internasional baru dihasilkan tepatnya setelah Majelis Umum PBB Deklarasi Universal HAM (Universal Declaration of Human Rights) pada tanggal 10 Desember 1948. Deklarasi ini merupakan ini merupakan dokumen intenasional pertama yang didalamnya berisi "katalog" HAM yang dibuat berdasarkan suatu kesepakatan internasional.

Kerana banyak pelanggaran HAM, maka banyak sekali pula tekanan-tekanan, baik dari dalam negeri maupaun dari luar negeri agar ada perlindungan HAM di Indonesia. Untuk menanggapi tekanan-takanan tersebut, dengan Keputusan Presiden Nomor 50 Tahun 1993 telah dibentuk Komisi Nasional Hak Asasi Manusia atau Komnas HAM yang kegiatanya antara lain memantau dan menyelidiki pelaksanaan HAM serta memberikan pendapat, pertimbangan dan saran kepada badan pemerintahan negara mengenai pelaksanaan HAM. Setelah zaman Orde Baru diganti dengan zaman Orde Reformasi, MPR baru berhasil membuat ketetapan mengenai HAM, yaitu Tap. MPR Nomor XVII/MPR/1998 tentang Hak Asasi Manusia yang naskahnya disusun sebagai berikut:

1. Pandangan dan sikap bangsa Indonesia terhadap HAM

2. Piagan HAM

Pada Pasal 44 Piagam HAM ditentukan bahwa untuk menegakkan dan melindungi HAM sesuai dengan prinsip negara hukum yang demokratis, maka pelaksanaan HAM dijamin, diatur, dan dituangkan dalam peraturan perundang-undangan. Atas dasar ketentuan yang terdapat dalam Pasa 44 Piagam HAM tersebut, maka dilahirkanlah Undang-Undang Nomor 39 Tahun 1999 tentang Hak Asasi Manusia

Didalam penjelasan umum Undang-Undang Nomor 39 Tahun 1999 disebutkan, antara lain : 
a. Pengaturan mengenai HAM ditentukan dangan berpedoman pada Deklarasi HAM-PBB, Konvensi PBB Tentang Penghapusan Segala Bentuk Diskriminasi Terhadap Wanita, Konvensi PBB Terhadap Hak-Hak Anak, dan berbagai instrumen internasional lain yang mengatur tentang HAM

b. Undang-Undang Nomor 39 Tahun 1999 adalah merupakan payung dari segala peraturan perundang-undangan yang mengatur tentang HAM, sehingga pelanggaran, baik langsung ataupun tidak langsung atas HAM dikenakan sanksi pidana, perdata, dan administrasi sesuai dengan ketentuan perundang-undangan.

Setelah lahirnya Undang-Undang Nomor 39 Tahun 1999, pada sidang tahunan MPR tahun 2000, MPR atas dasar Pasal 37 UUD 1945, telah mengadakan amandeman kedua UUD 1945, yaitu dengan menambahkan BAB XA tentang Hak Asasi Manusia yang terdiri dari Pasal 28a hingga Pasal 28j. Pada Pasal 104 ayat (1) UndangUndang Nomor 39 Tahun 1999 menentukan bahwa untuk mengadili pelanggaran HAM yang berat dibentuk pengadilah HAM di lingkungan Peradilan Umum. Atas dasar ketentuan yang terdapat dalam Pasal 104 ayat (1) Undang-Undang Nomor 39 Tahun 1999 tersebut, ditetapkan Peraturan Pemerintah Pengganti Undang-Undang Nomor 1 Tahun 1999 tentang Peradilan Hak asasi Manusia, namun tidak mendapatkan persetujuan dari DPR untuk menjadi Undang-Undang dan sebagai gantinya dilahirkanlah Undang-Undang Nomor 26 Tahun 2000 tentang Pengadilan Hak Asasi Manusia yang dimuat dalam Lembaran Negara RI Tahun 2000 Nomor 208, yang mulai berlaku pada tanggal 23 November 2000 dengan mencabut dan menyatakan tidak berlaku Peraturan Pemerintah Pengganti Undang-UndangNomor 1 Tahun 1999 tentang Peradilan Hak asasi Manusia sedang penjelasan UU Nomor 26 Tahun 2000 dimuat dalam Tambahan Lembaran Negara RI Nomor 4026. Didalam penjelasan umum Undang-Undang Nomor 26 Tahun 2000 disebutkan bahwa dengan adanya undang-undang ini diharapkan dapat melindungi HAM, baik perseorangan maupun masyarakat dan menjadi dasar dalam penegakan, kepastian hukum, keadilan dan perasaan aman baik bagi perseorangan maupun masyarakat terhadap pelanggaran HAM yang berat.

\section{Pembahasan}


Untuk menjamin pengakuan dan perlindungan terhadap HAM, Indonesia telah memiliki beberapa instrumen hukum yang berkaitan dengan HAM. Terkhusus untuk mengadili pelanggaran HAM berat, dilahirkan Undang-Undang Nomor 26 Tahun 2000 tentang pengadilah Hak Asasi Manusia. Didalam penjelasan umum UndangUndang Nomor 26 Tahun 2000, dibentuknya Pengadilan HAM tersebut dilaksanakan atas pertimbangan sebagai berikut :

1. Pelanggaran hak asasi manusia yang berat merupakan "extra ordinary crimes" dan berdampak secara luas baik pada tingkat nasional maupun internasional dan bukan merupakan tindak pidana yang diatur dalam Kitab Undang-Undang Hukum Pidana serta menimbulkan kerugian baik materiil maupun immateriil yang mengakibatkan perasaan tidak aman baik terhadap perseorangan maupun masyarakat, sehingga perlu segera dipulihkan dalam mewujudkan supremasi hukum untuk mencapai kedamaian, ketertiban, ketentrman, keadilan, dan kesejahteraan bagi seluruh masyarakat Indonesia.

2. Terhadap pelanggaran hak asasi manusia yang berat diperlkan langkahlangkah penyelidikan, penyidikan, penuntutan, dan pemeriksaan yang bersifat khusus. Kekhususan dalam penanganan pelanggaran hak asasi manusia yang berat adalah:

a. Diperlukan penyelidik dengan membentuk tim ad hoc, penyidik ad hoc, penuntut ad hoc, dan hakim ad hoc.

b. Diperlukan penegasan bahwa penyelidikan hanya dilakukan oleh Komisi Nasional Hak Asasi Manusia sedangkan penyidik tidak berwenang menerima laporan atau pengaduan sebagaimana yang diatur dalam Kitab Undang-Undang Hukum Acara Pidana.

c. Diperlukan ketentuan mengenai tenggang waktu tertentu melakukan penyidikan, penuntutan, dan pemeriksaan di pengadilan.

d. Diperlukan ketentuan mengenai perlindungan korban dan saksi.

e. Diperlukan ketentuan yang menegaskan tidak ada kadaluwarsa bagi pelanggaran hak asasi manusia yang berat.

Pengadilan HAM adalah pengadilan yang berada dilingkungan Peradilan Umum yang hanya bertugas dan berwenang untuk memeriksa dan memutus perkara pelanggaran HAM yang berat saja. Sampai saat sekarang baru 4 (empat) Pengadilan HAM yang dibentuk, yaitu Pengadilan HAM pada Pengadilan Negeri 
Jakarta Pusat, Pengadilan Negeri Surabaya, Pengadilan Negeri Medan, dan Pengadilan Negeri Makassar. Adapun untuk pelanggaran HAM berat yang terjadi sebelum diundangkanya Undang-Undang Nomor 26 Tahun 2000, diperiksa dan diputus oleh Pengadilan HAM Ad Hoc yang berada pada lingkungan Peradilan Umum yang pembentukannya atas usul Dewan Perwakilan Rakyat Republik Indonesia berdasarakan peristiwa tertentu dengan Kepurtusan Presiden. Dalam hal Dewan Perwakilan Rakyat Republik Indonesia mengusulkan dibentuknya Pengadilan HAM Ad Hoc, Dewan Perwakilan Rakyat Republik Indonesia mendasarkan pada dugaan telah terjadinya pelanggaran Hak Asasi Manusia yang berat yang dibatasi pada locus dan tempus delicti tertentu yang terjadi sebelum diundangkanya Undang-Undang Nomor 26 Tahun 2000 tentang Pengadilan Hak Asasi Manusia

\section{Lingkup Kewenangan Absolut}

Mengenai lingkup kewenangan absolut atau kompetensi absolut dari Pengadilan HAM , berdasarkan Pasal 4 dan 5 Undang-Undang Nomor 26 Tahun 2000, Pengadilan HAM bertugas dan berwenang untuk memeriksa dan memutus perkara pelanggaran HAM yang berat dan berwenang pula memeriksa dan memutus perkara pelanggaran HAM berat yang diluar batas teritorial wilayah negara Republik Indonesia oleh warga negara Indonesia. Pelanggaran HAM berat meliputi :

a. Kejahatan genosida yaitu : setiap perbuatan yang dilakukan dengan maksud untuk menghancurkan atau memusnahkan seluruh atau sebagian kelompok bangsa, ras, kelompok etnis, kelompok agama dengan cara :

- Membunuh anggota kelompok

- Mengakibatkan penderitaan fisik atau mental yang berat terhadap anggotaanggota kelompok

- Menciptakan kondisi kehidupan kelmopok yang mengakibatkan kemusnahan secara fisik baik seluruh atau sebagian

- Memaksakan tindakan-tindakan yang mencegah kelahiran didalam kelompok , atau memindahkan secara paksa anak-anak dari kelompok tertentu

b. Kejahatan terhadap kemanusiaan yaitu : salah satu perbuatan yang dilakukan sebagai bagian dari serangan yang meluas atau sistemik yang diketahuinya 
bahwa serangan tersebut ditujukan secara langsung terhadap penduduk sipil berupa :

- Pembunuhan

- Pemusnahan

- Perbudakan

- Pengusiran atau pemindahan penduduk secara paksa

- Perampasan kemerdekaan atau perampasan kebebasan fisik lain secara sewenang-wenang yang melanggar (asas-asas) ketentuan pokok hukum internasional

- Penyiksaan

- Perkosaan, perbudakan seksual, pelacuran secara paksa,pemaksaan kehamilan, pemandulan atau sterilisasi secara paksa atau bentuk-bentuk kekerasan seksual lain yang setara

- Penganiayaan terhadap suatu kelompok tertentu atau perkumpulan yang didasari persamaan paham politik, ras, kebangsaan, etnis, budaya, agama, jenis kelamin atau alasan lain yang telah diakui secara universal sebagai hal yang dilarang menurut hukum internasional

- Penghilangan orang secara paksa

- Kejahatan apartheid ( perbuatan tidak manusiawi yang dilakukan dalam konteks suatu rezim kelembagaan penindasan dan dominasi oleh suatu anggota kelompok rasial atas suatu kelompok atau kelompok-kelompok ras lain yang dilakukan dengan maksud untuk mempertahankan rezim tersebut.

Tidak semua perkara pelanggaran HAM yang berat menajdi lingkup kewenangan absolut atau kompetensi absolut dari Pegadilan HAM, karena Pasal 6 manentukan bahwa Pengadilan HAM tidak berwenang memeriksa dan memutus perkara pelanggaran HAM yang berat yang dilakukan oleh seseorang yang berumur dibawah 18 (delapan belas) tahun pada saat kejahatan dilakukan, yaitu suatu ketentuan yang sama dengan ketentuan yang terdapat dalam Pasal 26 Statuta Roma

\section{Lingkup Kewenangan Relatif}

Disamping menentukan tentang tempat kedudukan dari Pengadilan HAM, Pasal 3 ayat (1) Undang-Undang Nomor 26 Tahun 2000 juga menentukan tentang lingkup kewenangan relatif atau kompetensi relatif dari pengadilan HAM, yaitu daerah 
hukum Pengadilan HAM meliputi daerah hukum Pengadiln Negeri yang bersangkutan. Oleh karena sampai sekarang belum dibentuk Pengadilah HAM pada setiap Pengadilan Negeri, maka untuk mengetahui lingkup kewenangan relatif atau kompetensi relatif dari suatu Pengadilan HAM, harus dilihat pada keputusan Presiden tentang Pembentukan Pengadilan HAM yang bersangkutan.

Sebagai ketentuan peraliahan, oleh Pasal 45 ayat (1) jo. ayat (2) ditentukan pada saat muali berlakunya Undang-Undang Nomor 26 Tahun 2000 pada tanggal 25 Novermber 2000, dibentuk Pengadilan HAM, sebagai berikut :

a. Pengadialn HAM pada Pengadilan Negeri Jakarta Pusat dengan daerah hukum yang meliputi wilayah :

\section{a.1 Daerah Khusus Ibu Kota Jakarta}

a.2 Provinsi : Jawa Barat, Banten, Sumatera Selatan, Lampung , Bengkulu, Sumatera Barat, dan Kalimantan Tengah

b. Pengadialn HAM pada Pengadilan Negeri Surabaya dengan daerah hukum yang meliputi wilayah provinsi : Jawa Timur, Jawa Tengah, Bali, Kalimantan Selatan, Kaliantan Timur, Nusa Tenggara Barat, Nusa Tenggara Timur, dan Daerah Istimewa Yogyakarta

c. Pengadialn HAM pada Pengadilan Negeri Makassar dengan daerah hukum yang meliputi wilayah provinsi : Sulawesi Selatan, Sulawesi Tenggara, Sulawesi Tengah, Maluku, Maluku Utara, dan Irian Jaya

d. Pengadialn HAM pada Pengadilan Negeri Medan dengan daerah hukum yang meliputi wilayah provinsi : Sumatera Utara, Riau, Jambi, Sumatera Barat, dan Daerah Istimewa Aceh.

\section{Penyelidikan}

Pengertian penyelidikan menurut Undang-Undang Nomor 26 Tahun 2000 terdapat pada Pasal 1 ayat (5) yang menentukan bahwa yang dimaksud dengan penyelidikan adalah serangkaian tindakan penyelidik untuk mencari dan menemukan ada tidaknya suatu peristiwa yang diduga merupakan pelanggaran HAM yang berat guna ditindaklanjuti dengan penyidikan sesuai dengan ketentuan yang diatur dalam Undang-Undang Nomor 26 Tahun 2000. Penyelidikan terhadap Pelanggaran Hak Asasi Manusia yang berat dilakukan oleh Komisi Nasional Hak Asasi Manusia dan dalam hal melakukan penyelidikan tersebut Komisi Nasional Hak Asasi manusia 
dapat membentuk Tim Ad Hoc yang terdiri dari Komisi Nasional Hak Asasi Manusia dan unsur masyarakat sesaui ketentuan Pasal 18 ayat (2) Undang-Undang Pengadilan HAM.

\section{Penyidikan}

Di dalam Undang-Undang Nomor 26 Tahun 2000 tidak terdapat ketentuan tentang penyidikan. Oleh karena itu untuk mengetahui apa yang dimaksud dengan penyidikan dalam Undang-Undang Nomor 26 Tahun 2000, harus melihat pada ketentuan yang diatur dalam KUHAP. Pada Pasal 1 ayat (2) menetukan bahwa yang dimasud dengan penyidikan adalah serangkaian tindakan penyidik dalam dan menurut cara yang diatur dalam KUHAP untuk mencari dan mengumpulkan bukti yang denga bukti itu membuat terang tentang tindak pidana yang terjadi dan guna menemukan tersangkanya

Perbedaan mendasar antara penyelidikan dan penyidikan, jika dalam penyidikan tujuannya untuk menentukan ada atau tidaknya peristiwa pelanggran HAM berat, sedang dalam penyidikan tujuannya untuk memnetukan siapa tersangka yang dapat diduga melakukan pelanggaran HAM yang berat tersebut.

Kewenangan untuk melakukan penyidikan perkara pelanggarn Hak Asasi Manusia yang berat berada pada Jaksa Agung namun tidak termasuk kewenangan untuk menerima laporan dan pengaduan sebagai mana diatur dalam Pasal 21. Menurut Pasal 21 ayat (3), Jaksa Agung juga dapat mengangkat penyidik Ad Hok yang terdiri dari unsur pemerintah dan unsur masyarakat.

\section{Penangkapan}

Jaksa Sgung sebagai penyidik berwenang melakukan penagkapan untuk kepentingan penyidikan terhadap seseorang yang diduga keras melakukan pelanggran Hak Asasi Manusia yang berat berdasarkan bukti permulaan yang cukup dengan memperlihatkan surat tugas dan memberikan tersangka surat perintah penangkapan yang mencantumkan identitas tersangka dengan menyebutkan alasan penangkapan, tempat dilakukan pemeriksaan serta uraian secara singkat perkara pelanggran Hak Asasi Manusia yang berat yang dipersangkakan. Penangkapan dapat dilakukan paling lama 1 hari (Pasal 14 ayat 1,2, dan 5). Dalam hal tersangka tertangkap tangan, peangkapan dilakukan tanpa surat perintah dengan ketentuan 
bahwa penagkapan harus segera menyerahkan tertangkap bersama barang bukti kepada penyidik (Pasal 11 ayat 4).

\section{Penahanan}

Penahanan untuk kepentingan penyidikan dapat dilakukan paling lama 90 hari dan dapat diperpanjang paling lama selama 90 hari oleh Ketua Pengadilan HAM sesuai dengan daerah hukumnya. Jika proses penyidikan belum selesai selama jangka waktu sebagaimana di uraikan di atas, maka penahanan dapat diperpanjang paling lama 60 hari oleh Ketua Pengadilan HAM sesuai dengan daerah Hukumnya. Penahanan untuk kepentingan penuntutan dapat dilakukan paling lama 30 hari dan dapat diperpanjang paling lama 20 hari oleh Ketua Pengadilan HAM sesuai dengan daerah hukumnya. Dalam hal jangka waktu penahanan selama 50 hari telah habis sedangkan proses penuntutan belum dapat diselesaikan, maka penahanan dapat diperpanjang paling lama 20 hari oleh Ketua Pengadilan HAM sesuai dengan daerah hukumnya. Penahanan untuk kepentingan pemeriksaan di sidang pengadilan HAM dapat dilakukan paling lama 90 hari dan dapat diperpanjang untuk waktu paling lama 30 hari oleh Ketua Pengadilan HAM sesuai dengan daerah hukumnya. Penahanan untuk kepentingan pemeriksaan di tingkat banding di Pengadilan Tinggi dapat dilakukan paling lama 60 hari dan jangka waktu tersebut dapat diperpanjang untuk waktu paling lama 30 hari oleh Ketua Pengadilan Tinggi sesuai dengan daerah hukumnya. Penahanan untuk pemeriksaan Kasasi di Mahkamah Agung dapat dilakukan paling lama 60 hari dan jangka waktu tersebut dapat diperpanjang untuk paling lama 30 hari oleh Ketua Mahkamah Agung (Pasal 12-17).

\section{Penuntutan}

Seperti halnya apa yang dimaksud dengan penyidikan di dalam Undang-Undang Nomor 26 Tahun 2000 juga tidak terdapat ketentuan tentang apa yang dimaksud dengan penuntutan, yang ada hanya ketentuan tentang apa yang dimaksud dengan penyelidikan seperti yang terdapat dalam Pasal 1 angka 5. Oleh karena itu apa yang dimaksud dengan penuntutan dalam Undang-Undang Nomor 26 Tahun 2000, juga harus dilihat ketentuan dalam KUHAP

Pada Pasal 1 angka 7 KUHAP, yang dimaksud dengan penuntutan adalah tindakan penuntut umum untuk melimpahkan perkara pidana ke Pengadilan HAM yang 
berwenang dalam hal dan menurut cara yang diatur dalam KUHAP dengan permintaan supaya diperiksa dan diputus oleh hakim di sidang pengadilan. Dalam melaksanakan tugasnya sebagai penuntut umum, menurut Pasal 23 ayat (2) Jaksa Agung dapat mengangkat penuntut umum ad hoc yang terdiri atas unsur pemerintah dan unsur masyarakat

\section{Pemeriksaan di Sidang Pengadilan HAM}

Pemeriksaan perkara pelanggaran Hak Asasi Manusia yang berat sebagaimana dimaksud dalam ayat (1) dilakukan oleh Majelis Hakim Pengadilan HAM yang berjumlah 5 orang terdiri dari 2 orang Hakim pada Pengadilan HAM yang bersangkutan dan 3 orang Hakim Ad Hoc (Pasal 27 ayat 2). Hakim Ad Hoc pada Pengadilan Negeri dan Pengadilan Tinggi diangkat dan diberhentikan oleh Presiden selaku Kepala Negara atas usul Ketua Mahkamah Agung yang diangkat untuk masa waktu 5 tahun dan dapat diangkat kembali untuk 1 kali masa jabatan ( Pasal 28, Pasal 32 ayat 4). Sedangkan Hakim Ad Hoc pada Mahkamah Agung diangkat untuk satu kali masa jabatan selama 5 tahun (Pasal 33 ayat 5). Perkara pelanggaran Hak Asasi Manusia yang berat, diperiksa dan diputus oleh Pengadilan HAM dalam waktu paling lama 180 hari terhitung sejak perkara dilimpahkan ke Pengadilan HAM ( Pasal 31). Dalam hal perkara pelanggaran Hak Asasi Manusia yang berat dimohonkan banding ke Pengadilan Tinggi, maka perkara tersebut diperiksa dan diputus dalam waktu paling lama 90 hari terhitung sejak perkara dilimpahkan ke Pengadilan Tinggi (Pasal 32 ayat 2 ). Dalam hal perkara pelanggaran Hak Asasi Manusia yang berat dimohonkan kasasi ke Mahkamah Agung, perkara tersebut diperiksa dan diputuskan dalam waktu paling lama 90 hari terhitung sejak perkara dilimpahkan ke Mahkamah Agung (Pasal 33 ayat 1 ).

\section{Kompensasi, Restitusi dan Rehabilitasi}

Setiap korban pelanggaran Hak Asasi Manusia yang berat dan atau ahli warisnya dapat memperoleh kompensasi, restitusi dan rehabilitasi yang dicantumkan dalam amar putusan Pengadilan HAM (Pasal 35 ayat 1 dan 2) 
1. Kompensasi adalah : ganti kerugian yang diberikan oleh negara karena pelaku tidak mampu memberikan ganti kerugian sepenuhnya yang menjadi tanggung jawabnya.

2. Restitusi adalah ganti kerugian yang diberikan kepada korban atau keluarganya oleh pelaku atau pihak ketiga, dapat berupa pengembalian harta milik, pembayaran ganti kerugian untuk kehilangan atau penderitaan atau penggantian biaya untuk tindakan tertentu.

3. Rehabilitasi adalah pemulihan pada kedudukan semula, misalnya kehormatan, nama baik, jabatan atau hak-hak tertentu. Kompensasi, Restitusi dan atau Rehabilitasi diberikan kepada korban atau keluarga korban yang merupakan ahli warisnya (Pasal 1, Pasal 2 ayat (1) Peraturan Pemerintah Nomor 3 Tahun 2002 tentang Tata Cara Perlindungan Terhadap Korban dan Saksi dalam Pelanggaran Hak Asasi Manusia yang Berat)

\section{Komisi Kebenaran dan Rekonsiliasi}

Dalam Undang-Undang Pengadilan HAM memberikan alternatif penyelesaian pelanggaran Hak Asasi Manusia yang berat dilakukan di luar Pengadilan HAM yaitu dilakukan oleh Komisi Kebenaran dan Rekonsiliasi ( Pasal 47). Keberadaan Komisi Kebenaran dan Rekonsiliasi sebagaimana dimaksud dalam Ketetapan MPR-RI Nomor V/MPR/2000 tentang Pemantapan Persatuan dan Kesatuan Nasional dimaksudkan sebagai lembaga ekstra yudisial yang ditetapkan dengan UndangUndang yang bertugas untuk menegakkan kebenaran dengan mengungkapkan penyalahgunaan kekuasaan dan pelanggaran Hak Asasi Manusia pada masa lampau, sesuai dengan ketentuan hukum dan perundang-undangan yang berlaku dan melaksanakan rekonsiliasi dalam perspektif kepentingan bersama sebagai bangsa.

\section{Ketentuan Pidana}

Ketentuan pidana pelanggaran HAM yang berat sebagaimana yang dimaksud dalam Pasal 7 Undang-Undang Nomor 26 tahun 2000 terdapat dalam ketentuan-ketentuan, sebagai berikut : 
Setiap orang yang melakukan perbuatan sebagaimana dimaksud dalam Pasal 8 huruf a, b, c, d, atau e dipidana dengan pidana mati atau pidana penjara seumur hidup atau pidana penjara paling lama 25 (dua puluh lima) tahun dan paling singkat 10 (sepuluh) tahun.

\section{Pasal 37}

Setiap orang yang melakukan perbuatan sebagaimana dimaksud dalam Pasal 9 huruf $a, b, d, e$, atau j dipidana dengan pidana mati atau pidana penjara seumur hidup atau pidana penjara paling lama 25 (dua puluh lima) tahun dan paling singkat 10 (sepuluh) tahun.

\section{Pasal 38}

Setiap orang yang melakukan perbuatan sebagaimana dimaksud dalam Pasal 9 huruf $\mathrm{c}$, dipidana dengan pidana penjara paling lama 15 (lima belas) tahun dan paling singkat 5 (lima) tahun.

\section{Pasal 39}

Setiap orang yang melakukan perbuatan sebagaimana dimaksud dalam Pasal 9 huruf $f$, dipidana dengan pidana penjara paling lama 15 (lima belas) tahun dan paling singkat 5 (lima) tahun.

\section{Pasal 40}

Setiap orang yang melakukan perbuatan sebagaimana dimaksud dalam Pasal 9 huruf $\mathrm{g}, \mathrm{h}$, atau i dipidana dengan pidana penjara paling lama 20 (dua puluh) tahun dan paling singkat 10 (sepuluh) tahun.

\section{Pasal 41}

Percobaan, permufakatan jahat, atau pembantuan untuk melakukan pelanggaran sebagaimana dimaksud dalam Pasal 8 atau Pasal 9 dipidana dengan pidana yang sama dengan ketentuan sebagaimana dimaksud dalam Pasal 36, Pasal 37, Pasal 38, Pasal 39, dan Pasal 40. 
1) Komandan militer atau seseorang yang secara efektif bertindak sebagai komandan militer dapat dipertanggungjawabkan terhadap tindak pidana yang berada di dalam yurisdiksi Pengadilan HAM, yang dilakukan oleh pasukan yang berada di bawah komando dan pengendaliannya yang efektif, atau di bawah kekuasaan dan pengendaliannya yang efektif dan tindak pidana tersebut merupakan akibat dari tidak dilakukan pengendalian pasukan secara patut, yaitu

a. komandan militer atau seseorang tersebut mengetahui atau atas dasar keadaan saat itu seharusnya mengetahui bahwa pasukan tersebut sedang melakukan atau baru saja melakukan pelanggaran hak asasi manusia yang berat; dan

b. komandan militer atau seseorang tersebut tidak melakukan tindakan yang layak dan diperlukan dalam ruang lingkup kekuasaannya untuk mencegah atau menghentikan perbuatan tersebut atau menyerahkan pelakunya kepada pejabat yang berwenang untuk dilakukan penyelidikan, penyidikan, dan penuntutan.

2) Seorang atasan, baik polisi maupun sipil lainnya, bertanggung jawab secara pidana terhadap pelanggaran hak asasi manusia yang berat yang dilakukan oleh bawahannya yang berada di bawah kekuasaan dan pengendaliannya yang efektif, karena atasan tersebut tidak melakukan pengendalian terhadap bawahannya secara patut dan benar, yakni :

a. atasan tersebut mengetahui atau secara sadar mengabaikan informasi yang secara jelas menunjukkan bahwa bawahan sedang melakukan atau baru saja melakukan pelanggaran hak asasi manusia yang berat; dan

b. atasan tersebut tidak mengambil tindakan yang layak dan diperlukan dalam ruang lingkup kewenangannya untuk mencegah atau menghentikan perbuatan tersebut atau menyerahkan pelakunya kepada pejabat yang berwenang untuk dilakukan penyelidikan, penyidikan, dan penuntutan.

3) Perbuatan sebagaimana dimaksud dalam ayat (1) dan ayat (2) diancam dengan pidana yang sama sebagaimana dimaksud dalam Pasal 36, Pasal 37, Pasal 38, Pasal 39, dan Pasal 40.

\section{Penutup}


Untuk menjamin pengakuan dan perlindungan terhadap HAM, Indonesia telah memiliki beberapa instrumen hukum yang berkaitan dengan HAM. Terkhusus untuk mengadili pelanggaran HAM berat, dilahirkan Undang-Undang Nomor 26 Tahun 2000 tentang pengadilah Hak Asasi Manusia

Pengadilan HAM adalah pengadilan yang berada dilingkungan Peradilan Umum yang hanya bertugas dan berwenang untuk memeriksa dan memutus perkara pelanggaran HAM yang berat saja. Sampai saat sekarang baru 4 (empat) Pengadilan HAM yang dibentuk, yaitu Pengadilan HAM pada Pengadilan Negeri Jakarta Pusat, Pengadilan Negeri Surabaya, Pengadilan Negeri Medan, dan Pengadilan Negeri Makassar .

Mengenai lingkup kewenangan absolut atau kompetensi absolut dari Pengadilan HAM , berdasarkan Pasal 4 dan 5 Undang-Undang Nomor 26 Tahun 2000, Pengadilan HAM bertugas dan berwenang untuk memeriksa dan memutus perkara pelanggaran HAM yang berat dan berwenang pula memeriksa dan memutus perkara pelanggaran HAM berat yang diluar batas teritorial wilayah negara Republik Indonesia oleh warga negara Indonesia. Pelanggaran HAM berat meliputi kejahatan Genosida dan Kejahatan Kemanusiaan

Penyelidikan kasus pelanggaran HAM yang berat berda dalam kewenangan Komisi Nasional dan Hak Asasi Manusia. Sedang untuk penyidikan dan penuntutan berada dalam kewenanagan Jaksa Agung. Pemeriksaan perkara pelanggaran Hak Asasi Manusia yang berat sebagaimana dimaksud dalam ayat (1) dilakukan oleh Majelis Hakim Pengadilan HAM yang berjumlah 5 orang terdiri dari 2 orang Hakim pada Pengadilan HAM yang bersangkutan dan 3 orang Hakim Ad Hoc (Pasal 27 ayat 2).

\section{Daftar Pustaka}

\section{Buku}


Atmasasmita, Romli.2000. Pengantar Hukum Pidana Internasional. Refika Aditama. Bandung

Gultom, Binsar. 2009. Pandangan Kritis Seorang Hakim Dalam Penegakan Hukum di Indonesia. Pustaka bangsa press. Medan

Kaligis, O.C. 2002. Peradilan Politik HAM di Indonesia. O.C. Kaligis \& Associates, Jakarta

Lamintang. P.A.F. 1990. Hukum Pidana Indonesia. Sinar Baru. Bandung

Sujatmoko, Andrey. 2015. Hukum HAM dan Hukum Humaniter. Rajawali Pers. Jakarta

Wiyono, R. 2015. Pengadilan Hak Asasi Manusia di Indonesia. Kencana. Jakarta

\section{Peraturan Perundang-undangan}

Kitab undang-undang hukum acara pidana

Undang-undang dasar negara republik indonesia tahun 1945

Undang-Undang Nomor 39 Tahun 1999 tentang Hak Asasi Manusia

Undang-Undang Nomor 26 Tahun 2000 tentang Pengadilah Hak Asasi Manusia

Keputusan Presiden Nomor 50 Tahun 1993 telah dibentuk Komisi Nasional Hak Asasi Manusia

Tap. MPR Nomor XVII/MPR/1998 tentang Hak Asasi Manusia

Tap MPR-RI Nomor V/MPR/2000 tentang Pemantapan Persatuan dan Kesatuan Nasional 